\title{
Implication Of Good Corporate Governance And Leverage On Earnings Management
}

\author{
Joni Hendra ${ }^{1}$, Heri Koesharjono ${ }^{2}$, Seger Priantono ${ }^{3}$ \\ 1,2,3Fakultas Ekonomi, Universitas Panca Marga Probolinggo
}

A R T I C L E I N F 0

Article history:

Received 20

Desember 2017

Received in revised form

Accepted 12

Februari 2018

Available online 27

Februari 2018

\begin{tabular}{l}
\hline Kata Kunci: \\
Kepemilikan \\
Kelembagaan, \\
Komposisi komisaris \\
independen Komposisi \\
dewan direksi, Ukuran \\
perusahaan, Leverage, \\
Manajemen Laba \\
Keywords: \\
Institutional ownership, \\
Composition of \\
independent \\
commissioners \\
Composition of board \\
of directors, Size of the \\
company, Leverage, \\
Earnings Management
\end{tabular}

6 Januari 2018

\begin{abstract}
A B S T R A K

Manajemen perusahaan (agent) adalah pihak yang paling
berkepentingan untuk mempraktekkan manajemen laba untuk menipu pengguna laporan keuangan sehingga manajemen memperoleh keuntungan pribadi (memperoleh keuntungan privat). Selain itu, perusahaan dengan rasio leverage tinggi berpengaruh dalam melakukan praktik manajemen laba karena perusahaan dalam keadaan gagal bayar. Adanya asas tata kelola perusahaan yang baik diharapkan dapat meminimalisasi manajemen laba sehingga menghasilkan laporan keuangan yang tidak menggambarkan nilai fundamental perusahaan secara aktual. Studi yang bertujuan untuk menyatakan bahwa kepala pusing merupakan pengaruh yang signifikan antara kepemilikan institusional, komposisi komisaris independen. , ukuran dewan direksi, ukuran perusahaan dan leverage pada manajemen laba. Hasil penelitian terhadap perusahaan non bank yang terdaftar di LQ 45 di Bursa Efek Indonesia tahun 2013-2016 menunjukkan bahwa sebagian komposisi komisaris independen, ukuran perusahaan dan leverage berpengaruh positif terhadap manajemen laba. Saat diuji secara simultan menunjukkan bahwa kepemilikan instisional, komposisi komisaris independen, komposisi dewan direksi, ukuran perusahaan dan leverage berpengaruh signifikan terhadap manajemen laba. Ukuran perusahaan merupakan variabel penelitian yang memiliki pengaruh dominan terhadap manajemen laba, karena semakin besar ukuran atau skala perusahaan maka akan memudahkan perusahaan dalam memperoleh sumber pendanaan baik internal maupun eksternal.
\end{abstract}

A B S T R A C T

Company management (agent) is the party most concerned to practice earnings management to deceive the users of financial statements so that management gain private gain (obtaining privat gains). In addition, firms with high leverage ratios are influential in performing earnings management practices because the company is in default. The existence of the principle of good corporate governance is expected to minimize earnings management resulting in financial statements do not describe the fundamental value of the company actually. The study aims at stating wheader is proves significant influence between the institutional ownership, the composition of independent commissioners, the size of the board of directors, the size of the company and the leverage on earnings management.The results of research on non-bank companies listed in LQ 45 in Indonesia Stock Exchange year 2013-2016 show that partially the composition of independent commissioners, firm size and leverage have a positive effect on earnings management. When tested simultaneously indicate that instisional ownership, composition of commissioner independent, the composition of the board of directors, the size of the company and leverage have a significant effect on earnings management. The size of the company is a research variable that has a dominant influence on earnings management, because the larger the size or scale of the company it will be easier for the company in obtaining funding sources, both internal and external. 


\section{Introduction}

Many cases that occurred in Indonesia regarding the failure of Good Corporate Governance mechanism as happened in Sinar Mas Group company have violated the failure to publicly disclose material information in the form of signing settlement agreement with its creditor, not announcing annual financial report and not informing Bapepam regarding account receivable lawsuit in sufficient quantities of material. PT. Kimia Farma Company allegedly mark up the financial statements, which inflated profit Rp. 32.668 billion. Lippo Bank publishes 3 versions of the financial statements which are mutually different from one another, ie financial reports published in the mass media, reported to Bapepam, and to the company's managers. Implementation of the concept of Good Corporate Governance in Indonesia is expected to improve the quality of corporate performance and improve the welfare of shareholders.

Conceptually the mechanism of Good Corporate Governance, which is efforts to build equality, transparency, accountability, and responsibilitas in managing a company can be a hindrance to profit management activities. In general, earnings management is defined as an effort by the company's managers to interfere with or influence information information in financial statements in order to fool stakeholders who want to know the performance and condition of the company (Sulistyanto, 2008).

Earnings management is an intervention with a specific intention to the external financial reporting process intentionally to gain some personal gain. Dechow et al. (in Ujiantho and Pramuka, 2007). According to Subramanyam and Wild (2010: 131) that is "earnings cosmetic management is the result of freedom in accrual accounting applications that may occur". According to Sugiri (1998) in Ma'ruf (2006: 17) earnings management is defined as management behavior to "play" with the discretionary accruals component in determining the amount of earnings.Company management (agent) is the party most concerned to practice earnings management. The ultimate goal of management to earn earnings management is to trick users of financial statements so that management gets personal gain (obtaining privat gains).

Some parties who are harmed by earnings management practices include potential investors, creditors, suppliers, regulators, and other stakeholders. Boediono (2006) states that one efficient way to reduce the occurrence of conflicts of interest and ensure the achievement of corporate objectives need regulatory and control mechanisms, one of the mechanisms that can be used is to apply the mechanism of Good Corporate Governance.

The Forum for Corporate Governance (FCGI) in its first publication used the definition of the Cadbury Committee, in Retno and Priantinah (2012: 86): "A set of rules governing relationships between shareholders, managers (managers), creditor, government, other internal and external interest holders relating to their rights and obligations, or in other words a system governing and controlling the enterprise.

So companies that apply the principles of Good Corporate Governance will consistently improve the quality of financial statements and lower the level of profit management. Company performance as a benchmark for investors to see the development of the company, making managers will perform various ways to display the best performance, especially in a declining economic conditions. The financial statements are the sources of information used in assessing the performance or level of company health, so there are many possible managers to practice earnings management so that financial statements look good and meet the criteria for investors. The leverage ratio is the ratio found in the financial statements that can tell how big the company is financed by debt with the capability of the company described by capital, or it can also show some part of the assets used to guarantee the debt. Companies that have high leverage ratios, have an effect on performing earnings management practices because the company is in default, that is, it can not fulfill its debt obligations in time. Corporate governance indicators in this study include, constitutional ownership, independent commissioner composition, board size, company size, and leverage can also affect the occurrence of earnings management. This study is motivated by the results of different studies from previous studies.

Based on the objectives to be achieved, the following hypotheses can be proposed;

H1: Partially allegedly there is a significant influence between constitutional ownership, the composition of independent commissioners, the size of the board of directors, the size of the company and the leverage of earnings management.

H2: Suspected simultaneously there is a significant influence between the constitutional ownership, the composition of the independent commissioner, the size of the board of directors, the size of the company and the leverage to earnings management. 
H3: It is assumed that the independent commissioner composition variable has a dominant effect on earnings management.

Conceptually research or framework of thinking relationship between independent variable variable (X) with dependent variable (Y) can be shown in the picture below.

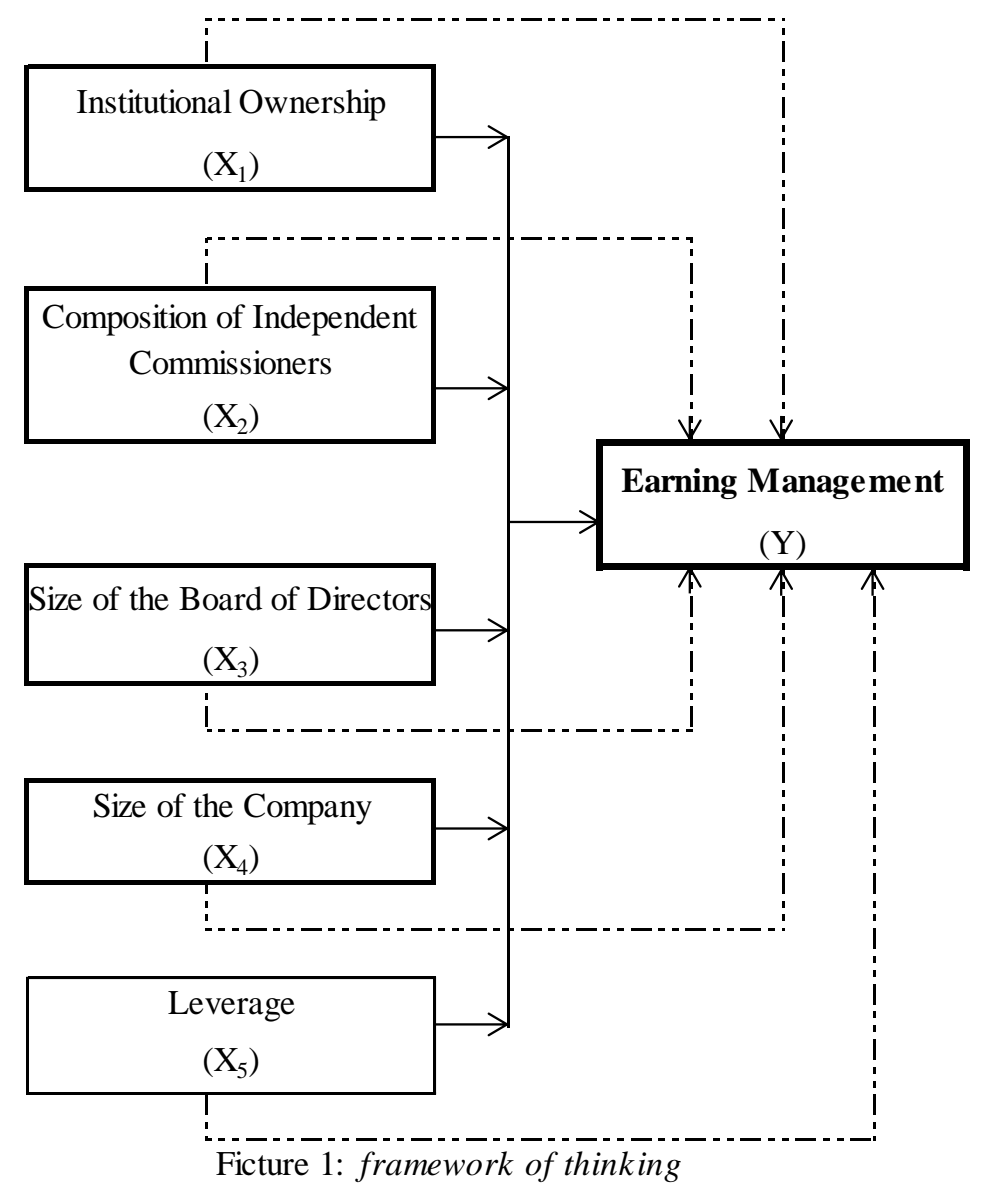

Good Corporate Governance Mechanism

The mechanism of corporate governance is divided into two groups: internal and external mechanisms. Internal mechanisms are a way to control a company by using internal structures and processes such as general shareholder meetings, board composition, board composition and board of director meetings. While external mechanisms are a way of influencing companies other than by using internal mechanisms, such as control by the company and market control (Dharmastuti, 2013: 23).

Institutional Ownership

Institutional ownership is the proportion of shares of companies owned by institutions such as insurance, banks, investment companies and other institutional ownership. Company management can increase institutional ownership so that the potential for financial distress can be minimized as firms with greater institutional ownership indicate their ability to monitor management. (Hery, 2017: 30).

Independent Commissioner

The Independent Commissioner is a member of the board of commissioners who has no financial, management, share ownership and / or family relationships with other members of the board of commissioners, directors and / or controlling shareholder or other relationship that may affect his ability to act independently (Puspitasari and Ernawati, $2010: 193-194)$.

Board of directors

Board of directors is also one of the indicators in the implementation of corporate governance responsible and responsible for running the company management. Hermalin and Weisbach (in Pratiwi, 2015) say that the number of members of the board of directors is generally related to the policy implications of the limit on the number of boards of directors.

The size of the firm

The size of the firm is a scale which can be classified by the size of the company in various ways, among others by total assets, stock market value, and others (Prasetyorini, 2013). 
Leverage

Leverage is an important tool in measuring the effectiveness of the use of corporate debt. This leverage concept is important for investors in making stock valuation judgments as investors generally tend to avoid risk (Hery, 2017: 12).

\section{Method}

This research is categorized into the type of descriptive verification research that is causality, by using quantitative method that examines a particular population or sample, data collection using research instrument, quantitative / statistical data analysis with the aim to test the correctness of the hypothesis set (Sugiyono, 2014).

The independent variables in this research are corporate governance mechanism, namely institutional ownership $\left(\mathrm{X}_{1}\right)$, independent board size $\left(\mathrm{X}_{2}\right)$, board size $\left(\mathrm{X}_{3}\right)$, company size $\left(\mathrm{X}_{4}\right)$, and leverage $\left(\mathrm{X}_{5}\right)$ with details as follows:

1. Institutional Ownership $\left(\mathrm{X}_{1}\right)$

Institutional ownership is the percentage (\%) of the number of shares held by the institution over the number of shares outstanding (Rice, 2016). Number of Institutional Shares

Institutional ownership =

Total percentage of Shares outstanding

2. Composition of Independent Commissioner $\left(\mathrm{X}_{2}\right)$

According to Hayati and Gusnardi (2015) the proportion of independent commissioners is measured by\% of the total number of independent board members of the total number of the company's board of commissioners and measured by the ratio scale. as follows :

$\begin{array}{llll}\text { Composition of } & \text { Independent } & \frac{\text { Number of }}{\text { Commissioners }} \\ \text { Commissioner }= & \begin{array}{l}\text { Total Members of the Board of } \\ \text { Commissioners }\end{array}\end{array}$

3. Board Size $\left(\mathrm{X}_{3}\right)$

According to Wulandari (2013) the size of the board of directors is the number of members of the board of directors in the company. The existence of the board of directors serves as the main internal control mechanism to monitor the managers of the company, the size of the board of directors is measured by:

Size of Board of Directors $=\Sigma$ Members of the Board of Directors

4. Company Size $\left(\mathrm{X}_{4}\right)$

Company size describes the size of a company indicated by total assets, total sales, and market capitalization. According to Rice (2016) The size of the company is how big the company is assessed from the amount of assets owned are:

Company Size (Size) $=$ In $($ Total Assets)

5. Leverage $\left(\mathrm{X}_{5}\right)$

The leverage ratio (leverage ratios) measures the extent to which the company's assets have been financed by the use of debt. The higher the leverage ratio, the more debt-financed assets by the creditors, thus indicating the company's risk in repayment, this may trigger earnings management practices. Leverage is measured by the ratio of total debt to total assets. (Ratio Debt to Asset (RDA)

Debt to Asset Ratio $=\frac{\text { Total Debt }}{\text { Total Asset }}$ X $100 \%$.... 5)

While the dependent variable (dependent variable) in this study is earnings management. Measuring earnings management using Discretionary Accruals (DAC), as a profit management proxy is calculated using the De-Angelo Model because this model is considered simpler among other models to measure earnings management. (Sulistyanto, 2008), with the calculation stage as follows: 1) Calculating the total accrual (TAC) value which is the difference of net income with operating cash flow (TAC = NI $\mathrm{CF}$ ) where $\mathrm{NI}=$ Net income, $\mathrm{CF}=$ Operating Cash Flow, $\mathrm{TA}=$ Total Assets, 2) Calculating the value of Nondiscretionary Accruals (NDA) which is the total average accrual (TAC) divided by total assets of previous periods by formula (NDA $=\mathrm{TAC} / \mathrm{TAF}$ ) where NDA $=$ Nondiscretionary Accruals, $\mathrm{TAF}=$ Total Assets Period, 3) Calculates the value of Discretionary Accruals (DA), ie the difference between total 
accrual (TAC) and Nondiscretionary Accruals (NDA). Discretionary Accruals (DA) is a profit management proxy by the formula (DA = TAC - NDA).

The population used in this study is a manufacturing company listed in the LQ-45 Index on the Indonesia Stock Exchange during the period 2013-2016. Sample selection using purposive sampling method based on several criteria as follows; 1) Companies that are consistently listed in the LQ-45 Index at the Indonesia Stock Exchange in the period 2013-2016, 2) Has published the complete annual financial report for the period of 31 December 2013-2016 in the Indonesia Stock Exchange or Indonesia Capital Market Directory (ICMD), 3) Disclose information about independent board of commissioners, institutional ownership, board of directors, company size and leverage, 4) Is a non-banking company. So the number of selected samples from poulasi that meet the criteria is as many as 34 companies.

\section{Result and Discussion}

The data used in this research is secondary data obtained from LQ-45 list at Indonesia Stock Exchange (IDX) and websiteidx year 2013-2016, with sample which fulfill criteria counted 34 company. The result of relationship analysis between independent variable $(\mathrm{X})$ and dependent variable $(\mathrm{Y})$ as follows table 1,

\section{Table 1}

Results of Multiple Linear Regression Analysis

\begin{tabular}{lccccc}
\hline \multicolumn{7}{c}{$\begin{array}{l}\text { Unstandardized } \\
\text { Coefficiens }\end{array}$} & \multicolumn{3}{l}{$\begin{array}{l}\text { Standardized } \\
\text { Coefficiens }\end{array}$} \\
\hline Model & $\mathrm{B}$ & std. Eror & Beta & $\mathrm{t}$ & Sig \\
\hline 1 (Constant) & 5673.016 & 3381.191 & 1.678 & .096 & \\
IO & 28.304 & 49.419 & .014 & .573 & .568 \\
CIC 10357.382 & 3208.072 & .085 & 3.229 & .002 & \\
BS & -892.778 & 496.363 & -.059 & -1.799 & .074 \\
CS & -.647 & .023 & -.908 & -27.766 & .000 \\
LVG & -8037.139 & 3415.624 & -.058 & -2.353 & .020 \\
\hline
\end{tabular}

Source: Data Processed 2017

The multiple regression equation obtained according to Table 1 above is $\mathrm{Y}=5673,016+28,304 \mathrm{X}_{1}+$ $10357,382 \mathrm{X}_{2}-892,778 \mathrm{X}_{3}-0,647 \mathrm{X}_{4}-8037,139 \mathrm{X}_{5}$. This form of regression equation has the following meanings:

1. Constanta $\mathrm{a}=5673,016$ This value of constants gives the sense that if the independent variables (institutional ownership, independent commissioner composition, board composition, firm size and leverage) are 0 , then profit management is worth 5673,016.

2. Regression coefficient $X_{1}$ (institutional ownership) $=28,304$. This coefficient gives the sense that if there is an increase of one unit of institutional ownership it will be followed by an increase in earnings management of 28.304 with other independent variables being considered constant.

3. Regression coefficient $X_{2}$ (independent board composition) $=10357,382$. This coefficient gives an understanding that if there is an increase of one independent board composition will be followed by an increase in earnings management of 10357,382 with other independent variables considered constant.

4. Regression coefficient $X_{3}$ (board size) $=-892,778$. This coefficient gives the sense that if there is an increase of one size the board of directors will be followed by a decrease in earnings management of 892.778 with other independent variables considered constant.

5. Regression coefficient $\mathrm{X}_{4}$ (firm size) $=-0.647$. This coefficient gives the sense that if there is an increase one size of the company will be followed by a decrease in earnings management of 0.647 with other independent variables are considered constant.

6. Regression Coefficient $X_{5}$ (leverage) $=-8037,139$. This coefficient gi ves the sense that if there is an increase of one leverage will be followed by a decrease in earnings management of 8037.139 with other independent variables are considered constant. 
First Hypothesis Testing ( $t$ test)

Table 2:

Based on the results of data analysis with partial testing can be shown in table 2 below:

Partial Test Results ( $\mathrm{t}$ test)

\begin{tabular}{|c|c|c|c|c|c|}
\hline \multirow[b]{2}{*}{ Model } & \multicolumn{2}{|c|}{$\begin{array}{l}\text { Unstandardized } \\
\text { Coefficiens }\end{array}$} & \multicolumn{2}{|c|}{$\begin{array}{l}\text { Standardized } \\
\text { Coefficiens }\end{array}$} & \multirow[b]{2}{*}{ Sig } \\
\hline & B & std. Eror & Beta & $\mathrm{t}$ & \\
\hline 1 (Constant) & 5673.016 & 3381.191 & 1.678 & .096 & \\
\hline IO & 28.304 & 49.419 & .014 & .573 & .568 \\
\hline CIC 10357.382 & 3208.072 & .085 & 3.229 & .002 & \\
\hline BS & -892.778 & 496.363 & -.059 & -1.799 & .074 \\
\hline $\mathrm{CS}$ & -.647 & .023 & -.908 & -27.766 & .000 \\
\hline LVG & -8037.139 & 3415.624 & -.058 & -2.353 & .020 \\
\hline
\end{tabular}

Source: Data Processed 2017

Based on the data in Table 2, it can be interpreted as follows; 1$)$ Institutional Ownership $\left(\mathrm{X}_{1}\right)$ is obtained tcount $(0,573)<$ ttabel $(2,268)$ and $p$-value $=0,568>\alpha 0,05$, this means institutional ownership $\left(\mathrm{X}_{1}\right)$ is partially significant but not significant to earnings management. Thus indicating that the increase in institutional ownership will be followed by improved earnings management, although not significant. 2) The composition of independent board of commissioners $\left(\mathrm{X}_{2}\right)$ obtained tcount $(3,229)>$ t.table $(2,268)$ and $p$-value $=0.002<\alpha 0.05$, this means that the composition of independent board of directors partially significant effect on earnings management. So it shows that if an increase in the composition of the board of directors Independent will affect the improvement of earnings management. 3) The size of the board of directors $\left(\mathrm{X}_{3}\right)$ obtained tcount $(-1,799)<$-ttable $(-2.268)$ and the value of $\mathrm{p}$-value $=0.074>\alpha 0.05$, this means the size of the board of directors partially influential but not significant to management profit. So it shows that the increasing number of board of directors will affect the decline in earnings management although not significant. 4) Company size $\left(\mathrm{X}_{4}\right)$ obtained by tcount $(-27,766)>$ ttable $(-2,268)$ and $\mathrm{p}$-value $=$ $0,000<\alpha 0,05$, this means firm size partially significant effect to earnings management. So this shows that the increasing size of the company will affect the decline in earnings management. 5) Leverage $\left(\mathrm{X}_{5}\right)$ obtained by $t$-value $(-2,353)>-$ ttabel $(-1,692)$ and $p$-value $=0,020<\alpha 0,05$, this means leverage partially significant effect to earnings management. So it shows that the increasing leverage will affect the decline in earnings management.

Overall the results of this test prove that "There is an influence between the institutional composition, the composition of the independent board of commissioners, the composition of the board of directors, the size of the company and the leverage partially on earnings management".

Second Hypothesis Testing (Test F) follows:

Based on the results of data analysis by simultaneous testing (Test F) can be shown in table 3, as

Table. 3

ANOVA Test

ANOVA $^{\text {b }}$

Model

Sum of

1. Regression

Squares

Residual

8.676E10

Total

$6.646 \mathrm{E} 9$

$9.341 \mathrm{E} 10$

\begin{tabular}{llcc}
\multicolumn{1}{c}{ df } & Mean Square & F & Sig \\
5 & $1735 \mathrm{E} 10$ & 339.446 & $.000^{\mathrm{z}}$ \\
130 & $5.112 \mathrm{E} 7$ & & \\
135 & & &
\end{tabular}

a. Predictors (Constant) X5, X4, X1, X2, X3

b. Dependent ariable $Y$

Source: Data processed 2017

Based on the data in Table. 3 above the test results show the value of $\mathrm{F}$ count (339.446)> Ftable (2.67) and $p$-value $=0,000<\alpha 0.05$ means that the independent variables simultaneously have significant effect on the dependent variable. Based on the $\mathrm{F}$ test results, it is proven that the first hypothesis can be accepted: "There is an influence between the institutional composition, the composition of the Independent board of commissioner, the composition of the board of directors, the size of the company and the leverage simultaneously to earnings management. 


\section{Third Hypothesis Testing (Dominant Test)}

From the Partial Test in the Standardized Coefficients Beta column can be known that the independent variable that has a dominant influence on the dependent variable is the variable $\mathrm{X}_{4}$ (company size) with the value of Standardized Coefficients Beta 0.908 greater than the value of Standardized Coefficients Beta other independent variables.Thus for the third hypothesis that the composition of independent commissioners has a dominant influence on earnings management, it is not proven Discussion

1. Results of testing the first hypothesis.

Partially institutional ownership $\left(\mathrm{X}_{1}\right)$ has no significant effect on earnings management. Thus institutional ownership is assumed to reduce the level of agency problems that arise within a company.

In the variable composition of independent commissioner $\left(\mathrm{X}_{2}\right)$ obtained the result that partially this variable significantly influence earnings management. Thus the composition of independent board of commissioners in the implementation of Good Corporate Governance is the most important part because responsible for overseeing all management actions in managing the company including the possibility of management take profit management action.

In the variable composition of the board of directors (X3) obtained the results that partially this variable has an effect but not significant to earnings management. So the board of directors should have a very important and strategic role in maintaining the credibility of the process of preparing financial statements so that control of the company will be less good and the agency conflict that occurs due to management' $s$ desire to improve their own welfare can be minimized.

In variable size of company (X4) obtained result that partially this variable have significant effect to earnings management. This can explain that the size of the company greatly affects the level of the company, meaning that the higher the size of the company will be followed the decline in earnings management, because the larger the size or scale of the company will be easier for companies in obtaining sources of funding, both internal and external

In the variable Leverage (X5) obtained the result that partially this variable also significant effect on earnings management. The results of this study are also in line with the results of Wulandari (2013) study indicating that individually institutional ownership and board composition have a negative effect on earnings management, while the composition of independent commissioners, firm size and leverage have a positive effect on earnings management.

2. Results of testing the second hypothesis

Based on the F test at the level of significance $\alpha=5 \%$ proved independent variables (institutional ownership, independent commissioner composition, board composition, firm size and leverage simultaneously significant effect on earnings management, where Fcount $<$ Ftabel $=(17,657<2.67)$ and the significance of the study appears to be greater than $\alpha 0,05(0,000>\alpha 0,05)$. Thus, Good Corporate Governance variables consisting of instisional ownership, the size of the composition of independent board of commissioners, the composition of the board of directors, the size of the company and the leverage can provide an explanation of the importance of the variables of Good Corporate Governance on earnings management. The results of this study are also in line with the results of Boediono's (2006) research that his research shows the size of the board of directors, the size of the company, the institutional ownership, and the composition of independent commissioners together affect the earnings management.

3. Results of testing the third hypothesis

From result of dominant test indicate that firm size have dominant influence to earnings management. This means that the higher the size of the company will be very influential on the level of earnings management decline. This is because large and medium sized companies have more aggressive effect on earnings management by always reporting positive earnings, to avoid reporting losses or decreasing profits.

The results of this study are similar to those performed by Khaerunnisa, Siti and Eko, Umanto. 2014, but not in line with the results of Wulandari's (2013) study, which shows the composition of the board of commissioners most dominant influence on earnings management. Similar research was conducted by Setiawan, Teguh. 2009 also failed to prove that the existence of the composition of independent commissioners has a significant positive effect on earnings management

\section{Conclusions and Recomendations}

Based on the results of the test in this study, it can be concluded as follows: 1) Partially indicates institutional ownership and the composition of the board of directors has no effect on earnings management, while the composition of independent commissioners positively affects earnings management, and for the composition of the board of directors, firm size and leverage negatively affect 
earnings management, 2) Simultaneously indicates instisional ownership, the composition of independent commissioners, the composition of the board of directors, the size of the company and the leverage effect on earnings management. 3) Variable size of the firm dominant influence on earnings management, it is indicated by the value of Standardized efficients Beta greater than the value of Standardized Coefficients Beta other independent variables.

The management of the company should improve the compositional quality of the board of commissioners, because in this study indicates that there are still many companies whose board of commissioners concurrently holds more than one position.

While the suggestions that can be given are: 1) Enterprise management should further improve the implementation of good corporate governance, so as to improve supervision of earnings management. 2) Further research needs to add some variables and increase the number of company population to be sampled so that not only manufacturing companies but also types of service companies listed on the Indonesia Stock Exchange

\section{References}

Boediono, Gideon SB. 2005. Kualitas Laba : Studi Pengaruh Mekanisme Corporate Governance dan Dampak Manajemen Laba dengan Menggunakan Analisi Jalur Simposium Nasional Akuntansi VIII Surakarta, Univ Sebelas Maret, 15-16 September 2005.

Bursa Efek Indonesia. 2016. LaporanKeuangan .http://www.idx.co.id

Dharmastuti, Christiana Fara. 2013. Analisis Pengaruh Mekanisme Internal Dan External Corporate Governance Terhadap Profitabilitas Dan Kebijakan Dividen Perusahaan (Studi Empiris Pada Perusahaan Go Publik Di Pasar Modal Indonesia). Jurnal Organisasi dan Manajemen. Volume 9, Nomor 1. Maret 2013.

Ghozali, H Imam.2011. Aplikasi Analisis Multivariat dengan Program SPSS, Edisi Ketiga. Semarang: Badan Penerbit Universitas Diponegoro.

Hayati, Annur fitri dan Gusnardi, 2012. Pengaruh Penerapan Mekanisme Good Corporate Governance terhadap Manajemen Laba. Jurnal Akuntansi. Vol. XVI. No. 03: 364-379. September 2012.

Hery, 2017. Kajian Riset Akuntansi : Mengulas berbagai hasil penelitian terkini dalam bidang Akuntansi dan Keuangan. Jakarta : Penerbit PT. Grasindo.

Khaerunnisa, Siti dan Eko, Umanto. 2014. Retno M., Reny Dyah dan Denies Priantinah. 2012. Pengaruh Good Corporate Governance dan Pengungkapan Corporate Social Responsibility Terhadap Nilai Perusahaan (Studi Empiris Pada Perusahaan yang Terdaftar di Bursa Efek Indonesia Periode 20072010).Jurnal Nominal.Vol. 1 No. 1.Juni 2016

Komite Nasional Kebijakan Governance, 2004.Pedoman Umum Good Corporate Governance Indonesia.http:www.governance-indonesia.or.id/main.htm

Ma'ruf, 2006. Analisis Faktor-Faktor Yang Mempengaruhi Manajemen Laba pada Perusahaan Go-Public di Bursa Efek Jakarta (BEJ). Tesis. Semarang: Universitas Diponegoro.

Priyatno, Dwi. 2009. Mandiri Belajar SPSS untuk Analisis Data \& Uji Statistik. Jakarta : Media Kom.

Pratiwi, F. L. 2015. Analisis Mekanisme Good Corporate Governance Terhadap Manajemen Laba Pada Perusahaan Manufaktur yang Terdaftar di BEI. Jurnal Riset Mahasiswa Akuntansi. ISSN: 2337-56xx. Vol.xx No.xx

Puspitasari, F. dan Ernawati E. 2010, Pengaruh Mekanisme Corporate Governance Terhadap Kinerja Keuangan Badan Usaha. Jurnal Manajemen Teori dan Terapan. Vol. 3. No. 2:189-215. Agustus 2010

Retno M., Reny Dyah dan Denies Priantinah. 2012. Pengaruh Good Corporate Governance dan Pengungkapan Corporate Social Responsibility Terhadap Nilai Perusahaan (Studi Empiris Pada Perusahaan yang Terdaftar di Bursa Efek Indonesia Periode 2007-2010). Jurnal Nominal. Vol. 1 No. 1 
Rice, 2016. Pengaruh factor keuangan terhadap Manajemen laba dengan corporate governance sebagai vaiabel moderating. Jurnal Wira Ekonomi Mukroskil. Vol. 6 No. 01 : 55 - 71. April 2016.

Setiawan, Teguh. 2009. Analisis Pengaruh Mekanisme Good Corporate Governance Terhadap Praktek Manajemen Laba Pada Perusahaan Manufaktur yang terdaftar di Bursa Efek Indonesia Periode 20052007. Jurnal Akuntansi Kontemporer. Vol. 1. N0. 2. Juli 2009.

Sugiyono, 2014. Metode Penelitian Pendidikan : Pendekatan kuantitatif, kualitatif dan R\&D. Jakarta : Alfabeta

Subramanyam dan Wild, 2010.Analisis Laporan Keuangan. Buku Satu, Edisi Kesepuluh, Jakarta: Salemba Empat.

Sulistyanto, Sri. 2008. Manajemen Laba: Teori dan Empiris. Jakarta: PT. Gramedia

Ujiantho, Arif Muh. dan B.A. Pramuka. 2007. Mekanisme Corporate Governance, Manajemen Laba dan Kinerja Keuangan. Simposium Nasional Akuntansi X. IAI. Makasar 2007

Wulandari, Rahmita, 2013. Analisis pengaruh Good Corporate Governance dan Leverage terhadap Manajemen laba. Skripsi. Semarang : Universitas Diponegoro. 